KRZYSZTOF R. PROKOP - GLIWICE

\title{
PIECĆ LISTÓW KS. BOLESŁAWA KUMORA DO KS. TADEUSZA GLEMMY Z LAT 1952-1957
}

Dnia 1 XII 2005 przypada 80. rocznica urodzin ks. prof. Bolesława Stanisława Kumora, którego wszakże nie ma już wśród żyjących. Od jego śmierci minęły zaledwie trzy lata (zmarł 23 X 2002), stąd też zbyt jeszcze wcześnie, by ktoś mógł pokusić się o monograficzne przedstawienie losów życiowych i pozycji w polskiej historiografii kościelnej tego uczonego. Nigdy natomiast nie jest za wcześnie, by przystąpić do gromadzenia i opracowania świadectw ilustrujących niezwykle wszak różnorodną działalność naukową ks. B. Kumora, od roku 1960 związanego z Katolickim Uniwersytetem Lubelskim - wpierw właśnie z Ośrodkiem Archiwów, Bibliotek i Muzeów Kościelnych, którego był początkowo sekretarzem (od tego też momentu należał do Komitetu Redakcyjnego półrocznika „Archiwa, Biblioteki i Muzea Kościelne”). Jego aktywność w środowisku akademickim posiada niewątpliwie bogate odzwierciedlenie w zachowanej dokumentacji urzędowej, obok której do wykorzystania przez przyszłego biografa pozostają również archiwalia osobiste, wchodzące w skład spuścizny po zmarłym. Wśród niej znajduje się zapewne obfita korespondencja, jaką uczony ten otrzymywał od rozlicznych osób oraz instytucji. $\mathrm{O}$ wiele jednak większy trud wiązać się będzie z dotarciem do listów skreślonych przez samego B. Kumora, rozproszonych póki co po wielu prywatnych zbiorach, po części wszakże znajdujących się już w zasobach archiwów, dokąd trafiły wraz z materiałami pozostałymi po innych zmarłych postaciach życia kościelnego i naukowego minionego stulecia. Ta właśnie korespondencja z oczywistych względów będzie dla potencjalnego biografa bardziej jeszcze interesująca, w niej bowiem znajdują odzwierciedlenie zamysły i plany tudzież decyzje podejmowane na różnych etapach drogi życiowej przez tegoż kapłana-uczonego, odnoszące się przy tym zarówno do spraw dużej, jak i mniejszej wagi. Niejeden $\mathrm{z}$ wątków, na jakie tamże historyk natrafi, wymagać będzie gruntowniejszego przeanalizowania i dogłębnego komentarza, skądinąd bowiem wiadomo, że w curriculum vitae $\mathrm{B}$. Kumora były również momenty z rozmaitych 
względów trudne - zwłaszcza we wczesnych latach życia i u progu działalności na niwie naukowej ${ }^{1}$.

Właśnie początków aktywności na polu badań nad historią Kościoła w Polsce, którym uczony ten poświęcić się miał w przyszłości niemal bez reszty, dotyczy pięć listów z lat 1952-1957, jakie wystosował on do ks. prof. Tadeusza Glemmy ${ }^{2}$ - związanego z Krakowem i miejscowym środowiskiem teologicznym wybitnego nowożytnika, profesora Wydziału Teologicznego Uniwersytetu Jagiellońskiego (w okresie okupacji hitlerowskiej oraz w pierwszych miesiącach powojennych jego dziekana). Był on uczniem słynnego ks. prof. Jana Nepomucena Fijałka, po którym też zajmował od r. 1930 uniwersytecką Katedrę Historii Kościoła w Polsce i prowadził przeznaczone dla odbywających studia filozoficzno-teologiczne alumnów wykłady oraz seminarium naukowe w tym zakresie. Pod jego też kierunkiem B. Kumor uzyskał 27 IV 1952 magisterium na Wydziale Teologicznym UJ, napisawszy pracę zatytułowaną Mikołaj Trąba - pierwszy prymas Polski, a następnie przystąpił do przygotowywania dysertacji doktorskiej, której temat brzmiał: Jan Ostroróg i reforma Kościoła w Polsce $w X V w^{3}{ }^{3}$ Jak wynika z zamieszczonych poniżej listów, była ona gotowa już w owym roku 1952, w którym późniejszy profesor Katolickiego Uniwersytetu Lubelskiego oraz Papieskiej Akademii Teologicznej w Krakowie ukończył studia i otrzymał święcenia kapłańskie (4 V tr.). Do obrony doktoratu na Wydziale Teologicznym UJ jednakowoż nie doszło, bowiem z początkiem roku akademickiego 1952/1953, po zaledwie kilkumiesięcznej pracy duszpasterskiej w parafii św. Jakuba Apostoła w Brzesku, neoprezbiter Bolesław Kumor skierowany został przez zwierzchność diecezjalną na studia specjalistyczne w zakresie teologii moralnej na Wydziale Teologicznym KUL. W świetle świadectwa, jakie stanowi publikowana tu korespondencja, młody kapłan diecezji tarnowskiej nigdy nie miał jednak wątpliwości, uprawianiu której dyscypliny chciałby się całkowicie poświęcić i choć w duchu posłuszeństwa przystapił do studiowania teologii moralnej, uzyskując nawet w tej dziedzinie licencjat tudzież podejmując prace nad doktoratem, stale jednak myślał o doktoryzowaniu się w zakresie historii Kościoła i nie ustawał w doskonaleniu swego warsztatu badawczego, jako mediewista. Ostatecznie jednak laury doktorskie ks.

${ }^{1}$ Zob. np. S. N a b y w a n i e c, Ksiadz Bolesław Kumor - profesor uniwersytetu, badacz dziejów, organizacji i ustroju Kościoła, „Analecta Cracoviensia”, 27 (1995) s. IX-XVI. Odnośnie do curriculum vitae B. S. Kumora także m.in. Księga jubileuszowa 50-lecia Katolickiego Uniwersytetu Lubelskiego, red. M. Rechowicz, Lublin 1969, wg indeksu; Księga pamiatkowa w 75-lecie Katolickiego Uniwersytetu Lubelskiego. Wktad w kulture polska w latach 1968-1993, red. M. Rusecki, Lublin 1994, wg indeksu (zwł. s. 411-412); G. P o 1 a k, Kto jest kim w Kościele. Ekumeniczne „, who is who” chrześcijaństwa w Polsce, Warszawa 1999, s. 200; Wspótcześni uczeni polscy. Słownik biograficzny, t. 2, red. J. Kapuścik, Warszawa 1999, s. 578-579; Encyklopedia katolicka, t. 10, Lublin 2004, kol. 222-223 (A. Weiss).

2 Archiwum Instytutu Wydawniczego „Nasza Przeszłość” w Krakowie [dalej cyt.: ANPKr], sygn. 50 - Listy do ks. Tadeusza Glemmy i oceny prac, cz. 1 [T. Adamski - B. Magott].

${ }^{3}$ Zob. N a b y w a n i e c, Ksiadz Bolestaw Kumor, s. XI; J. W o 1 n y, Laudacja [z okazji doktoratu honoris causa ks. Bolesława Kumora], w: Unia brzeska - przeszłość i teraźniejszość - 1596-1996, red. P. Natanek i R. M. Zawadzki, Kraków 1998, s. 11-12. Także K. R. Prokop, Ksiadz Tadeusz Glemma (1895-1958). Biografia kapłana i uczonego, „Studia Pelplińskie”, 28 (1999) s. 341. 
B. Kumor zdobył nie w Uniwersytecie Jagiellońskim pod kierunkiem ks. prof. T. Glemmy, jak pierwotnie zamyśliwał, lecz na KUL-u, gdzie jego promotorem został ks. prof. Mieczysław Żywczyński. Co więcej, ówże październik 1954 r., w którym 29-letni kapłan rodem z podsądeckich Szymanowic uzyskał doktorat z teologii, zapisał się w dziejach nauki polskiej niesławnym usunięciem z najstarszej polskiej Wszechnicy istniejącego tamże od r. 1397 Wydziału Teologicznego, co formalnie zadekretowane zostało jeszcze w sierpniu 1954 r. W dwa lata później, na fali „odwilży” związanej z wydarzeniami społeczno-politycznymi października 1956 roku, pojawiły się wprawdzie nadzieje na przywrócenie w strukturach Uniwersytetu Jagiellońskiego usuniętego Wydziału, co znajduje odzwierciedlenie również w os-tatnim z zachowanych listów ks. Bolesława Kumora do ks. Tadeusza Glemmy, ostatecznie jednak do tego nie doszło. Wbrew intencjom władz komunistycznych nauczania teologii w Krakowie na poziomie akademickim nie udało się wszakże wyrugować, w czym swój udział miał również systematycznie dojeżdżający tu z Lublina z wykładami, od roku 1967, ks. docent (a później profesor) B. Kumor, z tego tytułu wyróżniony po latach przez Papieską Akademię Teologiczną doktoratem honoris causa (19 XI 1996) ${ }^{4}$. Poprzez swoją aktywność akademicką na gruncie krakowskim niewątpliwie pragnął on spłacić dług, jaki sam niegdyś zaciągnął jako początkujący badacz, kiedy to zdobywał doświadczenie i umiejęt-ności pod kierunkiem ks. prof. Tadeusza Glemmy Zawsze też wspominał owego przedwcześnie zmarłego w roku 1958 uczonego jako swego pierwszego Mistrza na ścieżkach pracy historycznej. Tego dowód stanowi publikowana poniżej korespondencja.

W kontekście owych pięciu listów ks. Bolesława Kumora do ks. Tadeusza Glemmy warto wspomnieć też o pochodzących z tego samego zespołu archiwalnego, a mianowicie części spuścizny po ks. prof. Glemmie przekazanej przez jego siostrę, urszulankę m. Jadwigę Glemmównę, do Archiwum Instytutu Wydawniczego „Nasza Przeszłość” w Krakowie, pojedynczych listach dwóch innych historyków Kościoła, skierowanych do tegoż samego adresata. Przywołanie ich w ramach obecnego przyczynku znajduje uzasadnienie w okoliczności, iż treść tychże pozostaje w bliskim związku - jakkolwiek z zupełnie różnych względów - z dorobkiem naukowym ks. B. Kumora. Ów mianowicie swoją rozprawę doktorską, przedłożoną na Wydziale Teologicznym KUL, poświęcił Dziejom polityczno-geograficznym diecezji tarnowskiej, podczas gdy nad podobną tematyką praco-

\footnotetext{
${ }^{4}$ Zob. „Biuletyn Papieskiej Akademii Teologicznej w Krakowie”, 15 (1996/1997) s. 125-127.

${ }^{5}$ Por. słowa wypowiedziane przez ks. prof. B. S. Kumora przy okazji wręczenia 15 IV 1996, podczas uroczystego posiedzenia Senatu Papieskiej Akademii Teologicznej w Krakowie, dedykowanego mu tomu „Analecta Cracoviensia”: „Gdy byłem w szkole, to mi nawet do głowy nie przyszło, że będę mógł w Krakowie wykładać, być profesorem. To przyszło jakoś samo. Przecież tu dostałem pierwszy stopień naukowy - magisterium u niezapomnianego profesora, niezwykle dobrego Tadeusza Glemmy w 1952 r. Tu mi wszak przyjęto pracę doktorską (...). Do doktoratu nie doszło, bo mój biskup się nie zgodził, wysłał mnie na studia do Lublina, ale przecież tutaj, na dwukrotną prośbę ks. kard. Wojtyły, podjąłem wykłady i seminaria naukowe 1 X 1967 r.” - „Biuletyn Papieskiej Akademii Teologicznej w Krakowie", 14 (1995/1996) s. 79-80 (całość - s. 75-80: Wręczenie pamiątkowego tomu ,Analecta Cracoviensia” ks. prof. Bolestawowi Kumorowi).
} 
wał w tym samym czasie inny członek prezbiterium tarnowskiego, ks. dr Władysław Smoleń, ówczesny dyrektor Muzeum Diecezjalnego i wykładowca w Instytucie Teologicznym w Tarnowie (w przyszłości również profesor Katolickiego Uniwersytetu Lubelskiego, a uprzednio wicedyrektor Ośrodka Archiwów, Bibliotek i Muzeów Kościelnych KUL), który zamierzał poświęcić jej swoją rozprawę habilitacyjną. W tej sytuacji doktorat B. Kumora pokrzyżował mu powzięte niegdyś plany, czego dał wyraz w niedatowanym liście do ks. prof. T. Glemmy, pisząc tamże: „Temat pracy p.t. Historia diecezji tarnowskiej musiałem zarzucić jako tematy pracy habilitacyjnej. Zrobiono mi na KUL-u niezamierzoną dywersję. Jeden bowiem z naszych księży pisał tam pracę doktorską p.t. Polityczno-terytorialny rozwój diecezji tarnowskiej. W tym stanie rzeczy nie wypada mi występować z podobnym, choćby szerszym i ogólniejszym problemem, jako tematem habilitacyjnym. Oczywiście, że tematu tego nie zarzucam. $Z$ dalszym tokiem porządkowania i opracowywania naszego archiwum zbieram nadal materiały do monograficznej pracy o diecezji tarnowskiej"6. Ostatecznie habilitował się on z zakresu historii sztuki (rozprawa dotyczyła sławnego ołtarza Wita Stwosza w Krakowie), co jednak nastąpiło dopiero w r. $1963^{7}$.

Drugi list, na który chcemy tu wskazać, nosi datę: Kraków, 11 XII 1956, i wyszedł spod ręki o. prof. Hieronima Eugeniusza Wyczawskiego, niedoszłego następcy ks. prof. T. Glemmy na Katedrze Historii Kościoła w Polsce Wydziału Teologicznego UJ, od roku 1954 do śmierci związanego z Akademią Teologii Katolickiej w Warszawie (zmarł w r. 1993) ${ }^{8}$. W liście tym sformułowany został zamysł opracowania w perspektywie obchodów tysiąclecia włączenia Polski do rodziny państw chrześcijańskich monografii historycznej diecezji, której stolicą był (i jest nadal) Kraków. Jak pisał wówczas o. Wyczawski do swego niegdysiejszego mistrza uniwersyteckiego, „i Księdza Prałata i do pewnego stopnia mnie związało życie z diecezją krakowską, czy byśmy więc nie mogli napisać na milenium chrztu Polski wspólnymi siłami historii diecezji krakowskiej? Dla mnie byłoby zaszczytem współpracować z Księdzem Prałatem. Zdaję sobie sprawę, że przedsięwzięcie jest ogromne, że trud niewiele byłby mniejszy od napisania historii Kościoła w Polsce, ale sądzę, że przy Bożej pomocy można by to zrobić. Stawiając taką propozycję, daleki jestem od przeceniania swych zdolności, po-

${ }^{6}$ ANPKr, sygn. 51 - Listy do ks. Tadeusza Glemmy i oceny prac, cz. 2 [H. Malczyk - F. Żur]: Ks. Władystaw Smoleń do Ks. Tadeusza Glemmy - Tarnów, bez daty.

${ }^{7}$ Zob. Ksiega jubileuszowa 50-lecia, wg indeksu; Księga pamiatkowa w 75-lecie, wg indeksu (zw1. s. 463); S. P i e ch, Smoleń Władystaw (1914-1988), profesor Katolickiego Uniwersytetu Lubelskiego i Instytutu Teologicznego w Tarnowie, historyk sztuki kościelnej, muzeolog, w: Słownik polskich teologów katolickich, t. 8, red. J. Mandziuk, Warszawa 1995, s. 542-545; J. K u ś, Smoleń Władysław (1914-1988), ksiadz, historyk i historyk sztuki kościelnej, profesor KUL, muzeolog, w: Polski stownik biograficzny, t. 39, Warszawa - Kraków 1999-2000, s. 256-257.

${ }^{8}$ Zob. J. M a ndzi uk, Wyczawski Hieronim Eugeniusz (1918-1993), bernardyn, profesor Akademii Teologii Katolickiej w Warszawie, historyk Kościoła, w: Stownik polskich teologów katolickich, t. 8, s. 643-655; Ocalić od zapomnienia. Profesorowie Akademii Teologii Katolickiej w Warszawie we wspomnieniach wychowanków, red. J. M. Dołęga, J. Mandziuk, Warszawa 2002, s. 243 -274 . 
zwolę sobie jedynie zaznaczyć, że pewne studia w tym przedmiocie mam za sobą, a pod okiem Księdza Prałata łatwo poszłyby dalsze. Przychodzi mi bowiem taka myśl: Jeśli my tego nie uczynimy, nie wiem, czy znajdzie się prędko ktoś, kto by się tego mógł podjąć. Formułując to inaczej, sprawa odwlecze się ad Calendas Graecas, gdy nie stanie Księdza Prałata. Przepraszam, że tak śmiało piszę, ale kieruję się jak najlepszą intencją, jedynie względem na dobro sprawy. Jeśli da Bóg, że wróci nasz Wydział na Uniwersytet Jagielloński, przedsięwzięcie takie podniosłoby bardzo Fakultet w ogóle, a studium historii kościelnej w szczególności"9. I tu zatem znalazła wyraz nadzieja na powrót teologii w mury najstarszej polskiej Almae Matris, w obecnym kontekście bardziej wszakże interesuje nas sam ów zamysł opracowania wspólnymi siłami tych dwóch badaczy syntezy wielowiekowych dziejów biskupstwa krakowskiego. Rzucona przez o. H. E. Wyczawskiego inicjatywa nie została jednakowoż podjęta przez ks. T. Glemmę i w efekcie cały plan upadł. Dopiero w cztery dekady później, w związku ze zbliżającym się milenium organizacji diecezjalnej na ziemiach polskich, w tym i Kościoła krakowskiego, urzeczywistnienia tego rodzaju wielce pracochłonnego, ale zarazem i doniosłego dzieła, podjął się nie kto inny, lecz właśnie ks. B. Kumor. Nie wiemy, czy tamten niegdysiejszy zamysł był mu znany (wydaje się, iż raczej nie), a w każdym razie nie wspomina o nim w przedmowie do swego dzieła, którego inspirację przypisuje wyłącznie Ojcu Świętemu Janowi Pawłowi $\mathrm{II}^{10}$. Pozostaje natomiast faktem, iż właśnie temu badaczowi zawdzięczamy ostatecznie czterotomową, wydaną w latach 1998-2002 monografię historyczną diecezji krakowskiej w dobie przedrozbiorowej, pracę nad ukończeniem której przerwała wszakże śmierć uczonego.

\section{LISTY KS. BOLESŁAWA KUMORA DO KS. TADEUSZA GLEMMY ${ }^{11}$}

\section{1}

Ks. Bolestaw Kumor do Ks. Tadeusza Glemmy

Tarnów, 14 VI 1952

ANP, sygn. 50, k. [129]

Najprzewielebniejszy Księże Prałacie!

Donoszę uprzejmie, że w dniu 10 czerwca [1952] byłem u Ks. Prałata [Jana] Krzemienieckiego; Ks. Prałat przeglądnął pobieżnie moją pracę, jak również i ocenę tejże, wydaną przez Ks. Profesora. Po przeglądnięciu Ks. Prałat powie-

${ }^{9}$ ANPKr, sygn. 52 - [Listy do ks. Tadeusza Glemmy w sprawach wydawniczych].

${ }^{10}$ B. S. Kumor, Dzieje diecezji krakowskiej do roku 1795, t. 1, Kraków 1998, s. 17-18.

${ }^{11}$ Występujących w tekście listów skrótów nie rozwiązywano, zachowano także oryginalną pisownię wielkich i małych liter. 
dział: „Pracę przyjmuję, proszę tylko zastosować się do wskazówek i życzeń Ks. Prof. Glemmy".

Zwracam się przeto do Ks. Prałata z uprzejmą prośbą, by Ks. Prałat był łaskaw udzielić mi swych cennych uwag i wskazówek, dotyczących mej pracy. Ja będę w Krakowie we środę (18. VI.); gdyby Ks. Prałat był łaskaw poświęcić mi przynajmniej 10. min., to byłbym za to bardzo wdzięczny.

Łącząc wyrazy należnego szacunku, całuję ręce Ks. Prałata.

dn. 14 VI 1952

Ks. Kumor Bol.

Tarnów

Semin. Duch.

2

Ks. Bolestaw Kumor do Ks. Tadeusza Glemmy

Brzesko, 25 IX 1952

ANP, sygn. 50, k. [130]

$\dagger$

Najprzewielebniejszy Księże Prałacie!

Pracę p.t. Jan Ostroróg i reforma Kościoła w XV wieku poprawiłem według wskazówek Ks. Prałata; równocześnie postarałem się o jej przepisanie w odpowiedniej ilości egzemplarzy.

Byłbym bardzo wdzięczny, gdyby Ks. Prałat poświęcił mi jeszcze w poniedziałek (tj. 29 września) parę chwil czasu i udzielił dalszych wskazówek.

Łącząc wyrazy należnego szacunku i ucałowanie ręki dla Ks. Prałata, pozostaję

Brzesko, dn. 25. IX. 52.

Ks. Kumor Bolesław

3

Ks. Bolesław Kumor do Ks. Tadeusza Glemmy

Lublin, 16 I 1953

ANP, sygn. 50, k. [131]

$\dagger$

Najprzewielebniejszy Księże Prałacie!

Proszę wybaczyć łaskawie, że ośmielę się w tym liście usprawiedliwić moje tak długie «milczenie» i zapytać uprzejmie Ks. Prałata o ocenę mojej rozprawy doktorskiej. 
Otóż od dnia 1 października ub. r. J.E. Ks. Biskup Ordynariusz zwolnił mię [sic] z wikariatu w Brzesku i polecił mi udać się na dalsze studia teologiczne na K.U.L. w Lublinie, ale, niestety, polecono mi specjalizację w Teologii moralnej.

Ja jednak oprócz tego, tak jak rozpocząłem, tak i dalej chętnie kontynuowałbym dalej [sic] studia historyczne pod kierunkiem Ks. Prałata, bo przyznam się, że lubię historię. Spodziewam się również, że i Ks. Biskup pozwoli mi, może nawet w bliskiej przyszłości, zapisać się na Wydz. Humanistyczny.

Proszę też uprzejmie Ks. Prałata o łaskawe podanie mi oceny mojej pracy p.t. Jan Ostroróg $i$ reforma Kościoła w XV wieku (co sądzi o niej Ks. Prałat Krzemieniecki?) i możliwości uzyskania stopnia doktorskiego na U.J. w Krakowie.

Będę bardzo wdzięczny Ks. Prałatowi za tak łaskawą uprzejmość, a moją wdzięczność wyrażę w modlitwie.

Lublin, dn. 16. I. 53.

Ks. Kumor Bolesław

4

Ks. Bolestaw Kumor do Ks. Tadeusza Glemmy

Lublin, 10 III 1954

ANP, sygn. 50, k. [132]

$\dagger$ L. J. Ch.

Najprzewielebniejszy Księże Prałacie!

Proszę mi łaskawie wybaczyć, że ośmielam się zabierać nieco czasu Ks. Prałatowi, ale ponieważ uczeń najdłużej i najmilej wspomina pierwszego Mistrza, dlatego też i ja, wspominając zawsze z radością Ks. Prałata, mego pierwszego Mistrza w dziedzinie nauk historycznych, chcę się chętnie podzielić z Ks. Prałatem tym, co na tym polu w ostatnim roku zrobiłem.

Wpierw jednak składam serdeczne podziękowanie Ks. Prałatowi za przyjęcie i pozytywną ocenę mej pracy doktorskiej pt. Jan Ostroróg i reforma Kościoła w XV wieku; ucieszyłem się bardzo z tej wiadomości. Powiem prawdę - przykro mi jednak było, że idąc za wolą Ks. Biskupa Ordynariusza (jak to już uprzednio pisałem - jestem bowiem na Teologii moralnej) nie mogłem poddać się rygorozom doktorskim. Nie tracę jednak nadziei, że [w] przyszłości będę mógł się oddać w pełni ukochanym przez mnie studiom historycznym.

Tymczasem będąc na sekcji Teologii moralnej zdałem w tym roku akademickim rygoroza licencjackie z zakresu Teologii moralnej na podstawie pracy Problem apostatów w pokucie kościelnej do czasów św. Cypriana, napisanej pod kierownictwem Ks. Prof. J. Kellera. Pracę tę, opartą o źródła patrystyczne i najnowszą literaturę francuską i niemiecką, pisałem metodą historyczną. Całość obejmuje 100 stron druku maszynowego.

Obecnie przystąpiłem do pisania pracy doktorskiej, również z zakresu Teologii 
moralnej pozytywnej, na temat zagadnień pokuty kościelnej u św. Cypriana (ostatecznie jeszcze nie sprecyzowałem tematu).

Równocześnie nie tracę kontaktu z historią; uczęszczam na seminaria historyczne do Ks. Prof. M. Żywczyńskiego i Ks. Prof. M. Rechowicza. W zeszłym roku opracowałem historię parafii rodzinnej oraz zebrałem bibliografię do biskupstw i kapituł katedralnych w Polsce.

Najwięcej jednak czasu poświęciłem zbieraniu materiałów do historii polityczno-geograficznej naszej (tarnowskiej) diecezji od pierwszych chwil jej istnienia do naszych dni. Materiały te zresztą zbieram już od czterech lat. Wykorzystałem w tym celu Archiwum Kurii Metropolitalnej w Krakowie, Archiwum Kurii Diecezjalnej w Tarnowie, Kapituły Katedralnej w Tarnowiei Archiwum Państwowe byłego C.K. Namiestnictwa we Lwowie (z kopii przedwojennych). Materiał mam już w całości zebrany, a nawet już przepracowany. Myślę, że praca ta, oparta przede wszystkim na materiale archiwalnym, będzie najlepszą z dotychczasowych.

Spodziewam się też, że Ks. Biskup Ordynariusz zezwoli mi, może jeszcze w tym roku, zająć się spowrotem [sic] ukochaną przeze mnie historią.

Do listu, który kończę, załączam serdeczne ucałowanie rąk Ks. Prałata wraz z wyrazami należnego szacunku.

Lublin, 10. III. 54.

Ks. Kumor Bolesław Nowotki 5

\section{5}

Ks. Bolestaw Kumor do Ks. Tadeusza Glemmy

Lublin, 7 I 1957

ANP, sygn. 50, k. [133]

$\dagger$

Najprzewielebniejszy Księże Prałacie!

Ze szczerą radością biorę do ręki każdy list od Ks. Prałata, przypomina mi bowiem nasz „Polski Rzym” - Kraków, a przede wszystkim mego pierwszego Mistrza na ścieżkach pracy historycznej. Tak się dziwnie składa, że każdy kapłan najczęściej wspomina pierwszą placówkę pracy duszpasterskiej, zaś historyk chętnie powraca myślą do pracowni swego pierwszego Mistrza. Cieszę się bardzo i z prawdziwym zainteresowaniem przyjmuję każdą wiadomość o wznowieniu Wydziału Teologicznego na U.J.; jestem przeto bardzo wdzięczny Ks. Prałatowi za informacje przesłane na ten temat w ostatnim liście. O ile się orientuję, sprawa ta ma jak najlepsze poparcie wśród wykładowców i księży studiujących na K.U.L.-u.

Tymczasem ja nadal jestem w Lublinie; w tym roku kończę historię na Wydziale Humanistycznym. Prawdopodobnie w tym roku może pójdzie do druku moja rozprawa doktorska p.t. Dzieje polityczno-geograficzne diecezji tarnow- 
skiej. Obecnie zajmuję się problematyką parafialną w średniowieczu. Mam zgromadzony ogromny materiał, zwłaszcza archiwalny; na pierwszy plan myślę opracować problem zaniku parafii do końca XVI w.

Łącząc wyrazy serdecznej wdzięczności i szacunku, zapewniam o pamięci w Memento.

Lublin, dn. 7. I. 57.

Ks. Kumor Bolesław Nowotki 5 